\title{
Impacts of land use and land use changes on the resilience of beekeeping in Uruguay
}

\section{Malkamäki, Arttu}

2016-09

Malkamäki , A , Toppinen , A \& Kanninen , M 2016 , ' Impacts of land use and land use changes on the resilience of beekeeping in Uruguay ' , Forest Policy and Economics, vol. 70 , pp. 113-123 . https://doi.org/10.1016/j.forpol.2016.06.002

http://hdl.handle.net/10138/172954

https://doi.org/10.1016/j.forpol.2016.06.002

acceptedVersion

Downloaded from Helda, University of Helsinki institutional repository.

This is an electronic reprint of the original article.

This reprint may differ from the original in pagination and typographic detail.

Please cite the original version. 


\title{
Impacts of land use and land use changes on the resilience of beekeeping in Uruguay
}

Malkamäki, Arttu' ${ }^{1}$ Toppinen, Anne'; Kanninen, Markku².

${ }^{1}$ University of Helsinki, Department of Forest Sciences, Helsinki, Finland.

${ }^{2}$ Center for International Forestry Research, Bogor, Indonesia.

\begin{abstract}
We use a social-ecological systems framework and interview data from key informants to analyze the threshold dynamics underpinning the resilience of the local beekeeping sector, amidst changes in land use (management) and land use changes (conversions) that result from the expansions of the soy and eucalypt frontiers in Uruguay. Our results indicate that while agriculture began displacing grasslands that originally provided high yields of honey, afforestation now compensates those losses through the flowerings of Eucalyptus grandis. By extending the flowering season from six to eight months, beekeepers' dependency on tree plantations has increased. However, forestry enterprises are now shifting to plant more productive species that do not flower similarly, anticipating a threshold crossover to which the beekeepers may be unable to adapt. In conclusion, resilience of this environmentally sensitive livelihood has been suppressed primarily by land use changes that have introduced new costs and challenges into honey production. However, threshold dynamics that appear as multifaceted challenges faced by beekeepers occur also elsewhere in the system. Certain outcomes of the threshold dynamics similar to feedback loops in social-ecological systems were identified, including considerations of out-migration and change in occupation, of which ultimate impacts remain unclear. Most beekeepers still cope with the remaining viability, but it appears that the current resilience level does not allow for further harmful impacts. This case example of coupled social and ecological interactions through a livelihood lens gives rise to future research in evolving new dimensions to govern social-ecological systems in Uruguay and beyond.
\end{abstract}

\section{Keywords}

Afforestation; Investment; Land use; Livelihood; Local communities; Resilience

\section{Introduction}

Frameworks encompassing social-ecological systems have become popular in analyzing the cross-scale interactions between the coupled, coevolved, and reciprocal social systems (i.e. people and their needs) and ecological systems (i.e. nature and its exploitation) to address the most pressing sustainability challenges (Binder et al., 2013; Cash et al., 2006; Holling, 2001; Liu et al., 2015). While some frameworks aim to diagnose the nonlinear interactions and outcomes to allow relevant actors to make more conscious choices under uncertainty (e.g. McGinnis and Ostrom, 2014), others have shifted the focus of sustainability analyses from pursuing optimal states and maximum sustainable yields to resilience analyses (Anderies et al., 2004; Domptail et al., 2013; Folke et al., 2002; Walker et al., 2006, 2004). In this paper, the concept of resilience holds relevance.

Resilience refers to the ability of an actor (in case of social resilience) or an ecosystem (in case of ecological resilience) to counter external stressors and reorganize from a shock without losing its distinctive features (Adger, 
2006, 2000; Folke, 2006). Adaptability would refer to the capacity of an actor or an ecosystem to influence resilience without an external intervention (Walker et al., 2004; Vincent, 2007). Importantly, resilience implies changing productive and organizational patterns for absorbing disturbances, but only for as long as irreversible thresholds are not crossed (Folke et al., 2004; Walker and Meyers, 2004).

Ecological thresholds are linked to discrete disturbances or the accumulation of harmful impacts, and they are used to indicate the breakpoint between two alternate regimes that may have drastic impacts on ecosystem functioning (Folke et al., 2004; Renaud et al., 2010). For example, empirical research has shown that a certain level of habitat fragmentation reduces biodiversity in a forest (e.g. Andrén, 1994; Fahrig, 2003). Several examples of such ecological regime shifts that are often related to social standards exist (e.g. pollution or overexploitation), including rangelands, coastal waters, and lakes (Anderies et al., 2002; Bestelmeyer, 2006; Carpenter et al., 2001; Rönnberg and Bonsdorff, 2004).

Discussion around thresholds has recently focused on social thresholds that are crossed when the acceptable conditions turn into unacceptable conditions (Christensen and Krogman, 2012). Shrinking trust in a collective management system could exemplify an approaching social threshold (Walker et al., 2006). Crossed thresholds can be examined through the feedback loops that are reflected in the social (e.g. changes in institutions) or ecological (e.g. reduced functioning) system. Such attempts are constrained by the fact that thresholds in complex socialecological systems are dynamic and in constant interaction with each other (Folke et al., 2004; Walker and Meyers, 2004), but weakening resilience due to human or natural activity has been associated with an increased probability of nonlinear regime shifts (Scheffer et al., 2001). Transformability would refer to the capacity of an actor to create a fundamentally new system when thresholds are crossed (Walker et al., 2004).

Understanding resilience and thresholds is relevant for sensitive human populations that disproportionately rely on natural resources. Crossing of thresholds also tends to constrain adaptability by delivering new costs and challenges to such populations, in line with the feedback loops associated with regime shifts (Janssen and Scheffer, 2004; Moser and Ekstrom, 2010; Mwangi and Ostrom, 2009; Zenteno et al., 2014). Equally important is to identify fast (e.g. weather, seasonal yields, and technology) and slow (i.e. controlling, e.g. climate, genetics, soil, and culture) variables that trigger thresholds (Walker et al., 2012). In theory, ecosystem managers should be interested in both fast and slow variables, and awareness of the impacts of approaching regime shifts could thus alter the course of management (Christensen and Krogman, 2012; Walker and Pearson, 2007). Warning indicators can be developed to anticipate thresholds, but precision of such indicators has remained poor (Adger, 2006; Biggs et al., 2009).

This conceptual framework suits the context of Uruguay, where the intensifying land use (i.e. management) and land use changes (i.e. conversions) have become highly visible in the last two decades, and are driven by the economic forces underlying agriculture and afforestation (Figure 1). Landscapes in Uruguay have experienced a constant change since the $19^{\text {th }}$ century, when grazing began mixing in with the native shrubs and pampa grasslands (Brussa and Grela, 2007; Eva et al., 2002). According to latest census data from 2011 (DIEA, 2015), however, 
agriculture expanded from $4.1 \%$ of land area in 1990 to $9.2 \%$ in 2011. Afforestation increased from $1.1 \%$ to $6.1 \%$. These numbers only tell part of the story: agriculture has been characterized by soy plantations that expanded from $0.883 \mathrm{M}$ ha in 2011 to $1.321 \mathrm{M}$ ha in 2013; afforestation by eucalypt plantations that increased from $0.676 \mathrm{M}$ ha to 0.726 M ha (MGAP, 2015). The expansions have largely come at the expense of grasslands (Tommasino, 2010). Besides these changes in resource systems, annual precipitation has increased since the eighties and the local climate is projected to shift from subtropical to tropical by the end of this century (Bidegain et al., 2009).
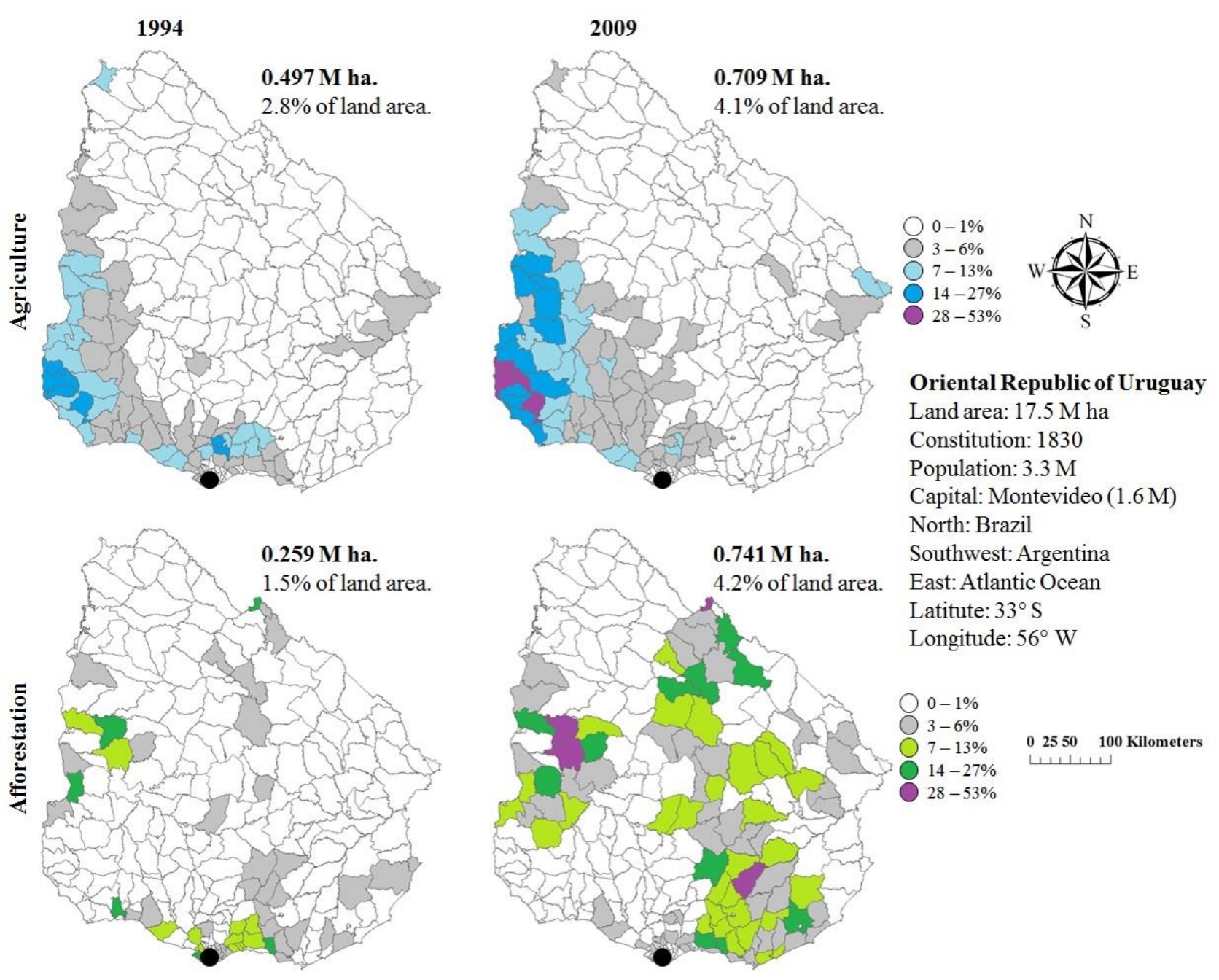

Figure 1. Changing patterns of agriculture and afforestation in Uruguay from 1994 to 2009 (adapted from Tommasino, 2010).

Expansion of the agricultural frontier in Uruguay has resulted from the modernization of agricultural practices and increases in the global demand of soybeans (Urcola et al., 2015; Volante et al., 2015). This frontier is advanced by a large and fragmented group of domestic and foreign landowners (Arbeletche and Carballo, 2009). Tree plantations in Uruguay began expanding after the approval of the Forestry Law 15.939 in 1987 that defined forestry land and provided initial subsidies to cover planting costs on soils of low productivity, and generous tax reliefs for upcoming sales gains. However, trends that frame the globalization of forestry, including the introduction of fast-growing eucalypt plantations that enable high productivity and profitability in the southern hemisphere, have largely contributed to this expansion (Cubbage et al., 2007; Korhonen et al., 2014; Toppinen et al., 2010). 
A parallel trend in this globalization process is the multinational forestry enterprises' increasing awareness of the roles of ecosystem benefits and community engagement that underpin their business success (Brody et al., 2006; D'Amato et al., 2015; Faggi et al., 2014). Those few enterprises that plant and manage eucalypt plantations on their own properties or leased lands in Uruguay have introduced programs that pursue synergies between plantation forestry and other rural livelihoods, including beekeeping. This tier of the local governance system is grounded in the idea of creating shared value ${ }^{1}$, and has offered beekeepers access for placing their hives in these forests since 2010 (Montes del Plata, 2015; UPM Forestal Oriental, 2013).

Uruguay has traditionally exported ca. 90\% of its honey (Uruguay XXI, 2014), and the existence of the sector is thus determined by external demand for this sweet substance. However, to survive and produce harvestable yields of honey, honeybees (Apis mellifera) need a variety of flowering floral resources that can be foraged alternately from early spring to late autumn (Bradbear, 2009). The practice of beekeeping, established in the grasslands in the western parts of the country several decades ago and chosen by many as a seemingly secure occupation after the regional economic recession in 2001 (Conforte et al., 2006), is thus likely to have been influenced by the changing patterns of land use. This also concerns the provision of pollination as an important ecosystem service for both nature and people (Gallai et al., 2009; Hanley et al., 2014; Klein et al., 2007).

Honeybees' tolerance to ecological changes has been actively studied due to rapid colony failures since 2007 (i.e. colony collapse disorder) (e.g. Barron, 2015; Potts et al., 2010). Capacity building of small-scale beekeeping in different contexts has been addressed (e.g. Strano et al., 2015; Vieira and Maia, 2009). Social and ecological concerns around large-scale tree plantations have been examined in the context of Uruguay (Paruelo, 2012; Silveira and Alonso, 2009; Switzer, 2014; Wang and Fu, 2013; Vihervaara et al., 2013, 2012), and reviewed across contexts (Bauhus et al., 2010; Brockerhoff et al., 2013; Charnley, 2005; Cossalter and Pye-Smith, 2003; Farley et al., 2005; Gerber, 2011; Ingram et al., 2016). However, while similar issues are likely related to the social-ecological system encompassing beekeeping, impacts of land use and land use changes on the resilience of beekeeping in Uruguay remain unclear Most research on sensitive social-ecological systems from a livelihood perspective has in fact considered aquatic ecosystems (e.g. Hunt et al., 2013; Rathwell and Peterson, 2012), and research on terrestrial ecosystems remains scarce and limited in focus and methods (cf. Lescourret et al., 2015).

To fill this gap, we use the presented framework to analyze interactions within and between social and ecological systems that encompass beekeeping in Uruguay. Our aim is to answer two questions: (i.) how have the land use and recent land use changes in Uruguay influenced the resilience and adaptability of the beekeepers, and (ii.) what kinds of threshold dynamics (crossed or approaching) can be identified with implications to beekeeping and the Uruguayan society? We will also discuss the governance implications with a focus on the expansion of tree plantations within and beyond the borders of Uruguay.

\footnotetext{
${ }^{1}$ Creating shared value relies on the idea that business decisions and social welfare are interdependent. Consequently, firms should integrate social perspectives into the frameworks that they use to understand and develop their business models. (Michelini and Fiorentino, 2012; Porter and Kramer, 2011, 2006; Prejer et al., 2014)
} 


\section{Methods}

A qualitative research method was selected to study the interactions in a complex social-ecological system. First, we reviewed papers published in scientific journals, grey literature, relevant statistics, and available brochures of the forestry enterprises. Second, we conducted thematic interviews in 2014 with representatives of four different informant groups that were expected to interconnect in the given system (Table 1). Some field notes were included.

Table 1. List of interviews in Europe and Uruguay.

\begin{tabular}{|l|l|l|l|l|}
\hline ID & Participant & Type & Length & Location \\
\hline Group A: Representatives of the honey processing industry in Europe \\
Nature of honey trade; reactions to the increasing uncertainty of supplies \\
\hline a1 & Supplier coordinator & Telephone & 30 min & Newcastle, GBR \\
\hline a2 & Sourcing director & Telephone & 40 min & London, GBR \\
\hline a3 & Purchasing manager & Telephone & 40 min & Gan, FRA \\
\hline
\end{tabular}

Group B: Spokesmen of governmental and non-governmental organizations in Uruguay

Role of local institutions; motivations and challenges for interventions; future prospects

\begin{tabular}{|l|l|l|l|l|}
\hline b1 & MGAP spokesman & In-person & $50 \mathrm{~min}$ & Office, Montevideo, UYU \\
\hline b2 & ADEXMI spokesman & In-person & $30 \mathrm{~min}$ & Office, Montevideo, UYU \\
\hline
\end{tabular}

Group C: Members of the agencies trading honey in and from Uruguay

Social and ecological processes of trading honey in and from Uruguay; spatial and temporal variations

\begin{tabular}{|l|l|l|l|l|}
\hline c1 & Sales manager & In-person & $40 \mathrm{~min}$ & Export facility, Montevideo, UYU \\
\hline c2 & Sales manager & In-person & $40 \mathrm{~min}$ & Export facility, Paysandú, UYU \\
\hline c3 & Sales manager & In-person & $30 \mathrm{~min}$ & Export facility, Flores, UYU \\
\hline
\end{tabular}

Group D: Beekeepers organized into cooperatives and individual practitioners in Uruguay*

Social and ecological processes of producing honey in Uruguay; spatial and temporal variations

\begin{tabular}{|l|l|l|l|l|}
\hline d1 & President of coop. X $(\mathrm{n}=1 /$ 8) & In-person & $60 \mathrm{~min}$ & Office, Durazno, UYU \\
\hline d2 & Members of coop. Y $(\mathrm{n}=9 / 23)$ & Group & $110 \mathrm{~min}$ & Extraction facility, Paysandú, UYU \\
\hline d3 & Members of coop. Z $(\mathrm{n}=5 / 82)$ & Group & $90 \mathrm{~min}$ & Extraction facility, Río Negro, UYU \\
\hline d4 & Members of coop. T $(\mathrm{n}=2 / 26)$ & Group & $60 \mathrm{~min}$ & Office, Colonia, UYU \\
\hline d5 & Individual practitioner & In-person & $50 \mathrm{~min}$ & Household, Durazno, UYU \\
\hline d6 & Individual practitioner & In-person & $60 \mathrm{~min}$ & Office, Paysandú, UYU \\
\hline d7 & Individual practitioner & In-person & $60 \mathrm{~min}$ & Office, Paysandú, UYU \\
\hline d8 & Individual practitioner (control) & In-person & $50 \mathrm{~min}$ & Household, Rocha, UYU \\
\hline
\end{tabular}

$* \mathrm{n}=$ number of members interviewed / reported total number of members in the cooperative.

Interviews were semi-structured to allow us to flexibly interact with the participants, add spontaneous inquiries to specify causes, and facilitate the outlining of qualitative insights (Warren, 2002). Question order slightly varied and occasional prompts were given to maintain the conversational style and natural flow of information. Questions were open-ended to allow the participants to interpret the question and provide self-generated responses. 
Since the existence of the beekeeping sector in Uruguay was determined by the export demand for honey, the initial interviews were organized with three representatives of the highly concentrated honey processing industry in Europe (Group A) (CBI, 2015a). Participants for telephone interviews were selected only if they had sourced honey from Latin America.

All other interviews were conducted in Uruguay (Table 2), in-person, to promote the open expression and comfort of participants (Shuy, 2002). Spokesmen of the Ministry of Agriculture, Livestock and Fisheries (MGAP, governmental organization) and the Honey Exporters Association (ADEXMI, non-governmental advocate pressing for better market conditions for Uruguayan honey) were interviewed to frame the role of local institutions (Group B). The selection of these two institutions was based on their alleged regulatory and market influences among the few local institutions that held ties to beekeeping in Uruguay. Despite our attempts, however, the spokesmen of the locally active environmental advocate (REDES) and industry conglomerate for the development of beekeeping (CHDA) could not be reached for a personal interview. Out of the ten agencies that buy honey from local beekeepers to aggregate exportable batches for sale, three members of different agencies were interviewed (Group C). In 2013, these three agencies traded $34 \%$ of the honey that left the country (Uruguay XXI, 2014).

Finally, we interviewed a set of practitioners of beekeeping (Group D). Four participants were individual practitioners with several hundreds of hives, while most practitioners with less hives had organized into cooperative structures. Beekeepers and cooperatives were selected as informants only if they had participated in at least one enterprise-led program, and thus had proven access to place their hives in tree plantations. As long as a person in a managerial role was able to participate, three of the four interviews with the different cooperatives were organized in a group format, which happened partly by coincidence. Despite the prolongation of one group interview with up to nine participants, these interviews in general resulted in informative outcomes from a qualitative data perspective as the participants' responses complemented each other alongside the lively discussion. 
Table 2. Interviews and the number of registered practitioners by department in Uruguay.

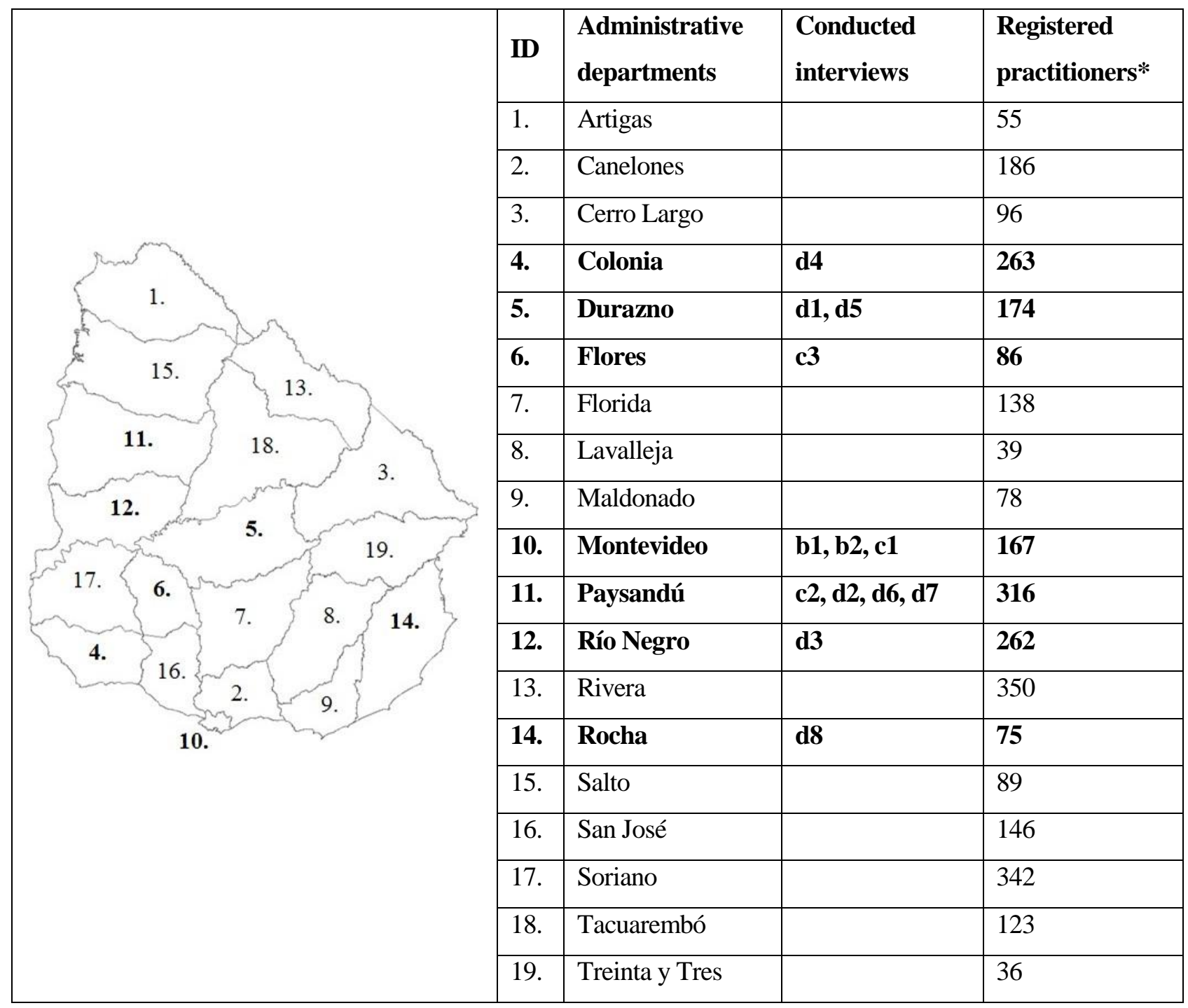

* 3021 practitioners had registered to formally be able to produce and trade honey in Uruguay in 2013 (Uruguay XXI, 2014).

To contact the beekeepers and cooperatives, we received information from various sources. Previous participants, program brochures, managers of the plantations, public databases, and websites we were given access to were helpful. The first author approached each participant as a scientific researcher via e-mail or telephone, explained the study purpose, and inquired about the participants' willingness to schedule an interview. Most beekeepers reside in western parts of the country where both agriculture and afforestation encounter (Figure 1; Table 2), which is why we controlled for one individual practitioner in the eastern department of Rocha. Topography in Rocha is more diverse and does not favor large-scale agriculture, but some of the hills in this department have been afforested.

A separate interview guide was designed for each of the four groups to operationalize the conceptual framework and examine the system dynamics through the concepts of resilience and thresholds (cf. Supplementary material). Participants in Group A were asked questions concerning the nature of the honey trade and their reactions to the increasing uncertainty regarding their supplies. Questions for Group B focused on the roles of local institutions relative to each other, the potential motivations and challenges for interventions, and the future prospects of the 
sector. Groups $\mathrm{C}$ and $\mathrm{D}$ were asked questions regarding the environmental and socioeconomic processes of trading and producing honey in Uruguay, including spatial and temporal variations as important for analyses of socialecological systems.

The most detailed interview guide was designed for representatives from Group D, as these were considered as the focal part of the given system. The guides for Groups B, C and D aimed to capture the nature and severity of the stressors on the resilience of the beekeeping sector, and examine the threshold dynamics and triggers in the resource systems with expected links to beekeeping. For example, recent shocks, their causes, and the subsequent responses and recovery mechanisms were inquired from the participants of these three groups. Also, both slow and fast variables such as honey yields, price shifts, climate, and changes in tenure regimes were inquired from the participants, but no specific variable to track the explicit locations of any predetermined ecological or social threshold could be designated in advance, as is common to complex social-ecological interactions (cf. Christensen and Krogman, 2012).

Each participant was assured of the confidentiality and encouraged to respond according to the personal opinions and experiences. We continued interviewing people in each group, except in Group A, until a mutual situational awareness, i.e. saturation of data (Strauss and Corbin, 1990), was achieved. Group A is an exception because the views between participants were more scattered. However, these interviews provided some detailed insights of the economic and political settings overarching the given system.

With permission from participants, all interviews in Uruguay were recorded in audiovisual format to provide a wider scope of observation, which proved helpful during the analysis. Data were first transcribed to run a content analysis. Transcriptions were printed and highlighters of different colors were used to divide the themes that arose from the data into either ecological or social categories. The cleaned data were additionally categorized according to recurring characteristics and analyzed further to synthesize the main properties of the given social-ecological system. Final interpretations were drawn and verified in a triangulation process, which worked as a way to combine and integrate data from different sources (Creswell, 2003; Miles \& Huberman, 1994).

Despite an abundance of data and diversity of themes that arose from the interviews and triangulation, we perceive that our research strategy succeeded in addressing the research questions. Data validity is thus perceived as high. However, we acknowledge that certain bias could underpin our data and methods. For example, fully generalizable results of qualitative data that are connected to a given point in time could not be produced, and the analysis is thus influenced by our own experiences and observations. Some individuals with opposing views could also have been excluded from our sampling. Group B is particularly susceptible to such issues as both participants' views could have been driven by underlying political agendas. In Group D, some individuals could have seized the opportunity to align their views in advance to use our research to leverage their own agendas. We did also receive minor technical assistance in terms of fieldwork and facilities from one of the affiliated enterprises, which could have led to similar outcomes. In these aforementioned cases, however, we could not find evidence of such influence. 
Participants' claims concerning the economic state of their household or their observations of the environmental changes must also be interpreted with caution. Generally, it should be taken into account that qualitative research methods tend to exclude alternative explanations, and are susceptible to intentional or unintentional misrepresentation of information due to participants' underlying motivations that we may not be aware of. However, use of triangulation has likely reduced these potential biases, and similar to most qualitative studies, authentic quotes are used in the text to improve the transparency of findings (Creswell, 2003).

\section{Results}

\subsection{Shifts in the resource systems and the impacts of these on beekeeping}

\subsubsection{Transition from pastures to plantations}

Agriculture and afforestation were reported by beekeepers as the main drivers of environmental change in Uruguay, but according to our finding these activities impact beekeeping in different ways. Area under agriculture has nearly doubled since 2009 (MGAP, 2015). This rapid expansion is characterized by extensive soy plantations (Glycine max), which could produce a nearly transparent honey appreciated by the processors, but the issue was found to be more complex. Soy plantations were claimed to occupy vast areas previously dedicated as grasslands for grazing, which contributed to beekeeping by offering a diverse variety of floral resources throughout the season. Most soy plantations were reported to represent monocultures and originate from transgenic seeds that are commonly resistant to herbicides used to control weeds, resulting in the extensive use of these chemicals. The decline in available floral resources resulted in the bees being less active than before the expansion of the agricultural frontier. The vitamin and protein shortages systematically reported by beekeepers had to be artificially substituted, resulting in increased costs in honey production. However, the individual practitioner in Rocha that we controlled for had not experienced similar impacts to similar extent. A quote from a beekeeper in the department of Colonia, where agriculture was widespread, reflects this issue:

Years ago, when the panel of the hive was removed, there was pollen of all different colors. Now there is just one color. The bees evidently also have worse nutrition. $-d 4$

Contrary to soy plantations, increase in the area under plantation forestry has been relatively steady in Uruguay since the nineties (MGAP, 2015). Tree plantations represent large-scale monocultures similar to soy plantations, but of a different character. Mainly arid and previously nutrient-poor grasslands were dedicated as forestry land and converted into plantations of different eucalypt (Eucalyptus spp.) species. However, these plantations were mostly under a stewardship certification, obliging their managers to conserve buffer zones and limit the spread of chemicals. The buffer zones with modest undergrowth on poor soils were found to benefit bees and beekeeping when compared to agricultural areas. While some practitioners appeared frightened of the use of chemicals in agriculture and its outcomes for bees, they were generally pleased with being able to place their hives within industrial tree plantations. 
This feeling of safety ${ }^{2}$ was found to be a valuable asset that is reflected in a quote from a cooperative member from Paysandú:

Tree plantations are healthy. They have the health we do not have in other lands. There is no risk of incident due to some herbicide. In this sense, well... Of course, it is certain we do not have the same variety of flowerings we could have in the grasslands or somewhere else, but nowadays, we prefer health over the impact of herbicides. We also have some flowerings of eucalyptus and shrubs in these lands. $-d 2$

\subsubsection{Selection of tree species as an approaching ecological threshold}

The recently established tree plantation ecosystems have transformed the nature of beekeeping in another important, but positive way. These ecosystems have added the flowerings of Eucalyptus grandis to the annual production cycle of honey, and a dark-colored and strong-flavored honey to the range of exportable varieties (Table 3). While the traditional way of producing honey in Uruguay relied on the rich floral resources of grasslands that are now decreasing, these flowerings have extended the production season from six to eight months. It was also found that under favorable weather conditions, E. grandis provides an additional harvest that has become overly important for beekeepers. In the western side of the country, this additional harvest has covered ca. $50 \%$ of the annual honey yields in recent years. Consequently, the sector has become dependent on the flowerings of eucalypts in a relatively short time, as this single harvest ensures that beekeepers overcome the issue of increased production costs. The average annual breakeven was reported to correspond to ca. $20 \mathrm{~kg}$ of honey per hive in all regions where interviews were conducted. The leader of a cooperative based in Durazno also commented on the increased importance of eucalypts in the following manner:

Previously the season used to end perhaps in February, and there was practically no honey to harvest in March, or very little. Now the season lasts until April, which is at least a month more of production, which has been very important. Last year before autumn, we only had very little honey, perhaps 10 to $12 \mathrm{~kg}$ per hive. (...) But when eucalyptus began flowering in March or April, we reached good production levels increasing the yield. (...) We have more and more beekeepers focusing on eucalyptus. (...) We have had an annual yield of 25 to $32 \mathrm{~kg}$ of honey per hive in the last years. $-d 1$

However, the choice of eucalypt species being planted plays a role for the beekeepers. In 2014, E. grandis and $E$. globulus were the most frequent species used in forestry in Uruguay, of which E. grandis begins flowering four years after being planted. E. globulus was reported to flower irregularly and only in the wintertime when bees do not forage actively. However, both species were reported to be replaced by other species, mainly by $E$. dunnii, which does not to floswer during its harvesting rotation of ca. 9 years. E. dunnii appears to be better suited for arid landscapes (cf. Thomas et al., 2009), as is the case in the regions where forestry is being practiced. The majority of

\footnotetext{
${ }^{2}$ Impacts of glyphosate, a broad-spectrum and post-emergent herbicide commonly used in agriculture, on Apis mellifera remain controversial in the scientific literature (Balbuena et al., 2015; Thompson et al., 2014).
} 
areas planted with E. grandis were also close to reaching maturity (Dirección General Forestal, 2012) that indicates that the landscapes filled with E. grandis are about to be converted to $E$. dunnii or other subspecies soon.

Table 3. Production cycle of honey in Uruguay.

\begin{tabular}{|c|c|c|c|c|c|c|c|c|c|c|c|c|}
\hline & \multicolumn{3}{|c|}{ Spring } & \multicolumn{3}{|c|}{ Summer } & \multicolumn{3}{|c|}{ Autumn } & \multicolumn{3}{|c|}{ Winter } \\
\hline & Sep & Oct & Nov & Dec & Jan & Feb & Mar & Apr & May & Jun & Jul & Aug \\
\hline Flowering type & \multicolumn{3}{|c|}{ Shrub } & \multicolumn{3}{|c|}{ Grassland } & \multicolumn{2}{|c|}{ Eucalypt } & \multicolumn{4}{|c|}{ Nectar not foraged actively } \\
\hline Nectar source & \multicolumn{3}{|c|}{$\begin{array}{l}\text { A variety, including: } \\
\text { Acacia caven } \\
\text { Citrus spp. }\end{array}$} & \multicolumn{3}{|c|}{$\begin{array}{l}\text { A variety, including: } \\
\text { Medicago sativa } \\
\text { Trifolium spp. } \\
\text { Lotus comiculatus } \\
\text { Baccharis articulata } \\
\text { Glycine max } \\
\text { Helianthus annus }\end{array}$} & \multicolumn{2}{|c|}{$\begin{array}{l}\text { E. grandis } \\
\text { E. saligna }\end{array}$} & \multicolumn{4}{|c|}{ E. globulus } \\
\hline Honey color* & \multicolumn{3}{|c|}{ Amber } & \multicolumn{3}{|c|}{ White } & \multicolumn{2}{|c|}{ Brown } & \multicolumn{4}{|c|}{ No honey produced } \\
\hline Hive management & \multicolumn{3}{|c|}{$\begin{array}{l}\text { Placement of hives } \\
\text { according to flowerings. } \\
\text { Organic control of } \\
\text { colonies and hives. } \\
\text { Artificial feeding, if } \\
\text { necessary. } \\
\text { Hiring temporary } \\
\text { manpower for harvest. } \\
\text { Extraction and packing } \\
\text { of honey. } \\
\text { Negotiating sales. }\end{array}$} & \multicolumn{3}{|c|}{ As on the left. } & \multicolumn{2}{|c|}{$\begin{array}{l}\text { As on the left. } \\
\text { Recycling } \\
\text { beeswax. }\end{array}$} & \multicolumn{4}{|c|}{$\begin{array}{l}\text { Registration to MGAP. } \\
\text { Registration of the extraction } \\
\text { facility to MGAP, if any. } \\
\text { Preparation of materials for the } \\
\text { next season. } \\
\text { Queens replaced every fifth year. } \\
\text { Artificial feeding to secure the } \\
\text { reproduction of the colony, if } \\
\text { necessary. } \\
\text { Chemical control of mites and } \\
\text { viruses. } \\
\text { Participation in training courses. }\end{array}$} \\
\hline Harvests** & \multicolumn{3}{|l|}{$0-1$} & \multicolumn{3}{|l|}{$1-2$} & \multicolumn{2}{|l|}{1} & \multicolumn{4}{|c|}{ No honey produced } \\
\hline Exports*** & \multicolumn{3}{|c|}{ Low season } & & & & & & & & & \\
\hline
\end{tabular}

* An important quality feature of honey as processors were found to prefer colorless and odorless honeys.

** Average numbers of harvests reported achievable during different seasons.

*** Trade agencies were found to aggregate exportable quantities of honey before contacting foreign buyers.

\subsubsection{Weather and climate as triggers of increasing pathogens and changing patterns of ground flora}

Beyond the aforementioned changes in the resource systems, regionally changing climate facilitated other changes with localized impacts on beekeeping. Confirmed by statistics, longer periods of drought and rainfall were generally reported to had become more frequent than previously, which affected the availability of floral resources and the behavior of the bees that tend to not leave their hives during rainfall (cf. Bidegain et al., 2009; Bradbear, 2009). Also, the recent proliferation of invasive and economically devastating mites, including Varroa destructor, is likely to result from inadequate management and transportation of bees, equipment, and beeswax on a global scale, but changing climatic conditions is deemed to have catalyzed their natural proliferation (Bradbear, 2009; Reddy et al., 
2013). Some related reflections of this evident slow variable, evoking faster variables such as pathogens, were delivered in the following comments:

It is all connected to the tolerance of our bees against a disease, varrosis. Now we are already completely exposed and Varroa is one of the main problems we have. And this appears at the same time as years of adverse weather, drought or radical rain. Last year, for example, another opportunist disease, nosemosis, appeared. This is on-going this year. (...) When an excessive drought or rain took place, people continued to sell meat. But if we do not provide sugar, we will not maintain the production, and we will not have honey. (...) Consequently, beekeeping is always more dependent on climate change. And we perceive it [the current situation] as bad. - b1

The climate is very important and nowadays its changes are much more radical, more extreme. A year of drought, another of rain. It is very difficult to find any good parts in this change. $-d 1$

\subsection{Shifts in the social system with impacts on the resilience and adaptability of the beekeepers}

\subsubsection{Changing land tenure and access to sources of flowering vegetation}

As beekeepers rarely own any land, the increased concentration of land tenure in the hands of investors operating from urban areas in Uruguay, or abroad, had complicated the negotiations over the placement of hives in some regions. The customary rule of placing hives is still based on an exchange between land access and the pollination of soil fertilizing plants (e.g. clover) or commercial crops to some extent, but as grasslands for grazing were found to be decreasing and the transgenic plants in agricultural areas do not require natural generation, we found these traditions to be fragmenting. This is an important observation from the beekeepers' perspective, as these informal rules have constituted the main form of compensation for pollination as a service. Access to land and the role of pollination emerged as issues in several discussions, including the following:

In this region, $80 \%$ of landowners owning the land where we place our hives are private companies. Argentinians... The problem is that when they arrive from abroad, they only do what they came for and leave. They never live in the countryside and we cannot communicate with them regarding any issues. The persons in charge here have no authorization. $-d 3$

In Uruguay, blueberries are pollinated. A single company pays us for the service. We are not paid by companies working in the grasslands, but at least we can still place our hives on their lands. This is done as a favor. If you own grassland, you let me bring the hives there as a shared favor. $-d 7$

To be able to place hives within the tree plantations, all the interviewed beekeepers had signed contracts with at least one of the forestry enterprises managing these plantations, and from the enterprise viewpoint these contracts represented their pursuit of shared value. For example, the contracts necessitate the beekeepers to study fire safety issues and they had had the chance to participate in capacity building and training courses that were organized by 
the enterprises, but they also had to pay these enterprises an annual fee ${ }^{3}$. Beekeepers residing in smaller urban centers in rural areas were also found to travel almost daily within an average radius of $50 \mathrm{~km}$ to conduct harvests or other hive management duties at one or more frequently relocated apiaries. In autumn, beehives were commonly placed on the outskirts of the often vast tree plantations, but the accessible areas were strictly coordinated by the plantation managers for reasons such as major tree harvests. However, fuel cost constituted one of the main elements associated with beekeeping in Uruguay, and the geographic scope and continuity of the accessible areas hence played a role for the beekeepers' livelihood.

\subsubsection{Social cohesion in the beekeeping sector}

The question of social cohesion among the sector also arose from our analysis, and was found to connect to several issues in the given social-ecological system. The interviews showed that the challenges resulting from the shifts in the resource systems increased the unity among beekeepers to counter the stressors. Beyond this common goal, several beekeepers were found to withdraw from beekeeping as their main source of income. It also appeared that beekeepers expressing pride and strong social motivations to remain as beekeeping practitioners had considered migrating to more favorable lands for beekeeping in the northeastern part of the country. Referring to the experiences of the other members of the same cooperative, a beekeeper remaining in Colonia shed light on this issue:

We do not have many artificial eucalyptus forests here, while they [beekeepers] in the north receive more honey as there are more eucalypts, (...) Most of all, Eucalyptus grandis provides a good yield. In Rivera, it [the annual yield] is $30 \mathrm{~kg}$, in Durazno $15 \mathrm{~kg}$, in Colonia $0 \mathrm{~kg}$ [per hive]. (...) Our cooperative has a contract with one corporation, but these forests are in Rio Negro... In the north, in Rivera, yes, it [income] is more secure. You may receive more or less [honey], but at least it [income] is more certain. (...) We enjoy beekeeping and that is why we are still here... But frankly, we should be moving to the north. We just lack the vehicle to move us, a place to live, an extraction facility ... $-d 4$

Another issue arose in terms of coordination of activities. All interviewed cooperatives reflected a lack of empowerment as none of the cooperatives had committed their members to act collectively in the production or marketing of honey, and thus elaborate on political or market power. Members were found to commit to cooperation only when predictable benefits seemed achievable, limiting the materialization of the anticipated benefits of cooperation.

However, trade agencies did not appear to be just opportunistic middlemen. The distribution of tasks was found to be natural since both the beekeepers and trade agencies specialize in what they do best. Interestingly, the margin left for the trade agency was low. The beekeepers reported to have received an average of ca. 3.00 USD per kg of

\footnotetext{
${ }^{3}$ The fee was found to correspond to the national average export price (3.16 USD per kg in 2013) of two kilograms of honey on average, depending on the plantation manager. For example, if a beekeeper placed 100 hives in a forest in 2013, the fee for this year (in fact, contracts were renewed in intervals of 11 months) would be 632 USD (3.16*2*100).
} 
honey in recent years, while the average export price of honey leaving the country was 3.16 USD in 2013 (Uruguay XXI, 2014). A trade agency member based in Paysandú drew an overall portrait of the current situation:

An export agency does not add any value to the product. But yes, in a way the agency is a tool from the beekeepers' point of view. Uruguay has no [export-oriented] beekeepers, or maybe a few, but the vast majority does not have the infrastructure in place to become exporters. $-b 2$

\subsubsection{Local institutional responses to fast shifts in the global honey markets}

Most honey from Uruguay is headed to Europe and North America, and European countries in particular apply strong safeguards to protect their consumers. Strict and frequently updated regulation, particularly in the European Union, has frequently redefined the technical composition and restricted the allowed amounts of chemical traces and contamination in honey with sudden outcomes in exporting countries (cf. CBI, 2015a; Villanueva-Gutiérrez et al., 2014). Some beekeepers and trade agencies also reported recent incidents of rejected and returned batches of honey due to detected traces of alkaloids or transgenic organisms in the pollen, originating from agriculture.

Due to consumer preferences, however, the interviewed European buyers and processors of honey considered these safeguards only as minimum requirements. There are numerous suppliers of honey globally, and the buyers clearly take advantage of their position to avoid market risks, resulting in the small honey sector in Uruguay being stuck in captive market structures. Such asymmetry of power was reflected, and explained to some extent, by one of the European industry representatives:

One of the things I should also say... This is a commercial matter. We do not have to go too much into detail... Honey is quite a dangerous trade... A very complicated trade... You know, and a.... Of course, the supply sources can be fairly remote, they can be fairly non-commercial... Mexico has a bad reputation for contractual defaults. In other words, if the market price of Mexican honey goes up, they do not ship with cheaper prices... So we apply minimum margins... We do not conduct this business for nothing, because it is very risky. Because if there is a problem in the supermarkets, we have to take it all back. It is an expensive business and an awful lot of things can go wrong. So... It is obviously a commercial business like the rest of the businesses here, just with lower margins. $a 2$

To respond to the concerns of the sector, the Uruguayan national government began developing a specific program (Sistema Nacional de Trazabilidad de la Miel) in 2006 to ensure the market access of Uruguayan honey, including efforts to build technical capacity and ensure full traceability (CHDA, 2011). These measures have increased the resilience and coordination of the sector, but simultaneously increased the costs of transactions and compliance. Likely catalyzed by these increased costs, the members of the cooperatives in Río Negro and Paysandú expressed frustration as the government lacked continuity in its efforts and was perceived to favor other sectors that were more important in pure economic terms: 
"Support? No. What they [government] do is they pay a lot of money to the technicians. They pay for the technicians, but that leads to there being no continuity. A technician comes and works on his project, collects the money, and we will never see him again. Continuity does not exist. It is one of the main problems we face." (...) The division of the MGAP responsible for beekeeping annoys me. They compensate all the lost harvests of other sectors, e.g. viticulture. They pay compensation when grapes have a low sugar contents. They pay us 21 pesos per hive due to rain or drought. Against 15 to $20 \mathrm{~kg}$ of honey per hive, this certainly does not leave us anything. It is less than a dollar. $-d 3$

We may receive some materials yes, but support is minimal. But we are able to rent this facility with help from MGAP and the departmental government. The institutions are important, but they lack commitment. They should have a much more important role in terms of development. Recently they have launched projects, but perhaps their economic resources cannot offer us more. MGAP also lacks competent human resources. $-d 2$

\section{Discussion and conclusions}

We used a social-ecological system framework to examine the properties, disturbances, and threshold dynamics that either promote or suppress the resilience of beekeeping sector in the case Uruguay. Qualitative data were collected by conducting thematic interviews with identified key informants in the given system both in Europe and Uruguay in 2014.

Investments in soy and eucalypt frontiers were identified to drive land use and land use changes, and declining biodiversity, in western parts of Uruguay where beekeeping has been concentrated since many decades. From the perspective of the practitioners of beekeeping, expansion of agriculture and tree plantations had rather contrasting impacts. According to our findings, the beekeepers were concerned about the expansion of agriculture displacing grasslands rich in floral resources. Reduced availability and variety of plants were associated with the decreased honey yields, and shortages of natural vitamins and proteins elementary for the bees. Manual substitution of such shortages does not come without additional costs. The simultaneous emergence of eucalypt plantations, managed by multinational forestry enterprises, had compensated these losses. E. grandis provides an additional harvest to atone decreasing yields from other sources, of which the beekeepers have become dependent on. Flowerings of this particular species constituted ca. $50 \%$ of the annual honey yields. Beyond land use changes, the changing weather and climate patterns appear to exacerbate the ecological stressors by increasing the occurrence of harmful pathogens on bees. The economic impacts are felt by the beekeepers, but not only in Uruguay.

Following from the shifts in resource systems, establishing land tenure forms another issue from the governance perspective. The forestry enterprises allow beekeepers to place their hives in their lands after signing a contract and paying a fee. Compared to the previous setting based on an exchange between access to land and pollination service, however, these arrangements add further costs to beekeeping. In fact, the challenges faced by beekeepers result from the strictly reciprocal influences and shifts in both the ecological and social systems (cf. Walker and Meyers, 2004). The case of Easter Island has become a famous example of similar shifts in both the ecosystem and society 
where resource overexploitation ultimately led to halving population (Hunt and Lipo, 2009; Rainbird, 2002). The case of Uruguay may not be as dramatic, but the slow variables such as declining biodiversity and warming climate clearly are the underlying controls of fast variables such as unbalanced flowerings throughout the season, rainy weather, yields, and costs, which all have implications to beekeeping as a form of livelihood. Recent institutional and market shifts have been fast as well, but the strong and slowly changing cultural ties could also be seen to contribute to building cohesion and cooperation among the beekeeping sector to counter some of the current stressors.

To conclude our first research question, it can be said that the recent land use changes have had a drastic and widespread influence on beekeeping in Uruguay, largely pushing these rural practitioners at the brink of a social collapse. On one hand, the negative impacts can be largely linked to the expansion of the agricultural frontier. On the other hand, tree plantations have not been as devastating, vice versa, but have created an interdependency between the beekeepers and the forestry enterprises in charge of the accessibility, management, and selection of species as a form of land use. Consequently, social resilience of the beekeepers has suffered from the disturbances created by land use changes in Uruguay while there never was much adaptability in the first place. These results are also in line with those reported by Switzer (2014).

Regarding our second research question, it can be said that the accumulation of new costs that primarily derive from the recent land use changes, threatens beekeeping's viability, and many beekeepers consider either abandoning this occupation completely or out-migrating to more natural areas in northern Uruguay. By definition, both of these outcomes could be interpreted as feedback loop to crossed thresholds that have ultimately been triggered by decreasing honey yields and increasing costs in production (cf. Janssen and Scheffer, 2004). However, the ultimate impacts of out-migration or change in occupation remain unclear and could even take rather unexpected forms (cf. Gray and Bilsborrow, 2014). As economic viability can be broadly understood as the focal threshold for many small-scale practitioners, the threshold dynamics that undermine social or ecological resilience can be relatively hard to distinguish, even in well-studied social-ecological systems (Folke et al., 2004). This result is in line with the one of Zenteno et al. (2014), indicating that thresholds occur as multifaceted socioeconomic challenges for the forest communities in Bolivia. In Uruguay, turning back could still be possible unless there would be a reason to anticipate the crossing of a critical social-ecological threshold related to land use. Most plantations of E. grandis are already reaching maturity and the new generation consists of other species that are not likely to provide similar short, but vast flowerings to benefit the beekeepers. Such change that would cut ca. 50\% of the annual honey yields in western Uruguay could be followed by societal responses such as conflicts (Gerber, 2011; Kovács et al., 2014). As reflected in our results, however, land use and land use changes cannot be blamed for every single challenge confronting beekeeping. In fact, Uruguay could be experiencing a "contemporary restructuring" that could also be seen as an opportunity, depending on the transformability of the entire society (cf. Hedlund and Lundholm, 2015).

Resilience of beekeeping could be targeted by rearranging benefit-sharing mechanisms, by prioritizing needs in the society, or by changing the rationale, attitudes, structure of social networks, or ways of collective action (Akamani 
et al., 2015; Cinner et al., 2012; Nkhata et al., 2012; Tucker, 2010). Consequently, governing social-ecological systems becomes the most relevant issue, referring to multilevel social, economic, and political settings that enable the society to define and accept alternative agendas, and alleviate mutually harmful outcomes and impacts (Brondizio et al., 2009; Duit et al., 2010).

From the perspective of the beekeepers in Uruguay, the European regulation of transgenic organisms in honey has already eased since 2014, which could signal that planting transgenic trees also in Uruguay, similar to neighboring Brazil that was the first country to legalize such plantations for commercial purposes in 2015, could be recommendable. The expected efficiency gains in wood production could in fact spare more diverse lands for beekeeping (cf. Ledford, 2015; Preisler, 2015), and thus contribute to forest transition (Rudel et al., 2010). Also, the forestry enterprises' pursuit of shared value could become an attractive option for locally solving social and ecological issues. As our results show, this approach requires engagement to tackling of identified problems that goes beyond the philanthropic view into creating shared value (cf. Beschorner, 2013; Crane et al., 2014). However, as beekeeping is connected to the valuable ecosystem service of pollination, establishing a well-designed program of payments for ecosystem services complemented with a well-functioning regulatory framework could help to reconcile priorities in the society and to prevent the exacerbation of associated social costs (Bennett and Gosnell, 2015; Börner et al., 2015; Naeem et al., 2015).

Further research should aim to generalize beyond the scope and findings presented here, and run trade-off analyses (e.g. Nelson et al., 2009), model decision-making of different agents under uncertainty (e.g. Janssen and Ostrom, 2006), or evaluate the social-ecological interactions quantitatively (e.g. Bodin and Tengö, 2012). Such assessments could consider other groups of actors that operate in the tree plantation landscape (cf. Bussoni et al., 2015), disaggregate by gender (cf. Ingram et al., 2014), and even incorporate a spatial view (cf. Sunderlin et al., 2008). Water is another theme that emerges. Availability of water enables the rich flowerings of $E$. grandis that favor the beekeepers, and could thus explain the reduced runoffs associated with eucalypt plantations to some extent (Farley et al., 2005). Water also controls for undergrowth and constitutes the main public concern around plantation establishment in Uruguay (Vihervaara et al., 2012). We also advocate for harnessing the concept of "social license to operate" to deepen the analyses of power, urgency, and legitimacy of the forestry enterprises to operate more soundly in social-ecological systems (e.g. Prno \& Slocombe, 2014).

\section{Acknowledgements}

We would like to express our sincere gratitude to everyone who participated in the interviews and the anonymous reviewers for their apt remarks. We wish to thank the staff of Stora Enso and Montes del Plata in Uruguay for their technical support in terms of fieldwork and facilities, and Stella Thompson from the Language Centre of the University of Helsinki for performing an apt language check on the first version of the manuscript. Insightful comments from the reviewers of this journal are gratefully acknowledged. All remaining errors are our own. Finishing this study was made possible by the Doctoral Program on Sustainable Use of Renewable Natural Resources at the University of Helsinki. 


\section{References}

Adger, W.N., 2006. Vulnerability. Glob. Environ. Chang. 16, 268-281. doi:10.1016/j.gloenvcha.2006.02.006

Adger, W.N., 2000. Social and ecological resilience: are they related? Prog. Hum. Geogr. 24, 347-364. doi:10.1191/030913200701540465

Akamani, K., Wilson, P.I., Hall, T.E., 2015. Barriers to collaborative forest management and implications for building the resilience of forest-dependent communities in the Ashanti region of Ghana. J. Environ. Manage. 151, 11-21. doi:10.1016/j.jenvman.2014.12.006

Anderies, J., Janssen, M., Ostrom, E., 2004. A Framework to Analyze the Robustness of Social-Ecological Systems from an Institutional Perspective. Ecol. Soc. 9, 18. doi:www.ecologyandsociety.org/vol9/iss1/art18/

Anderies, J.M., Janssen, M.A., Walker, B.H., 2002. Grazing management, resilience, and the dynamics of a fire-driven rangeland system. Ecosystems 5, 23-44. doi:10.1007/s10021-001-0053-9

Andrén, H., 1994. Effects of Habitat Fragmentation on Birds and Mammals in Landscapes With Different Proportions of Suitable Habitat - a Review. Oikos 71, 355-366. doi:10.2307/3545823

Arbeletche, P., Carballo, C., 2009. La expansión agrícola en Uruguay: Algunas de sus principales consequencias. Rev. Desarro. Rural y Coop. Agrar. 12, 7-20.

Balbuena, M.S., Tison, L., Hahn, M.-L., Greggers, U., Menzel, R., Farina, W.M., 2015. Effects of sub-lethal doses of glyphosate on honeybee navigation. J. Exp. Biol. doi:10.1242/dev.117291

Barron, A.B., 2015. Death of the bee hive: understanding the failure of an insect society. Curr. Opin. Insect Sci. 10, 45-50. doi:10.1016/j.cois.2015.04.004

Bauhus, J., van der Meer, P., Kanninen, M., 2010. Ecosystem Goods and Services from Plantation Forests. Earthscan, London.

Bennett, D.E., Gosnell, H., 2015. Integrating multiple perspectives on payments for ecosystem services through a social-ecological systems framework. Ecol. Econ. 116, 172-181. doi:10.1016/j.ecolecon.2015.04.019

Beschorner, T., 2013. Creating Shared Value: The One-Trick Pony Approach. Bus. Ethics J. Rev. 1, 106-112. doi:doi.org/10.12747/bejr2013.01.17

Bestelmeyer, B.T., 2006. Threshold concepts and their use in rangeland management and restoration: The good, the bad, and the insidious. Restor. Ecol. 14, 325-329. doi:10.1111/j.1526-100X.2006.00140.x

Bidegain, M., Crisci, C., del Puerto, L., Inda, H., Mazzeo, N., Taks, J., Terra, R., 2009. Clima de Cambios: Nuevos Desafíos de Adaptación en Uruguay. Montevideo. doi:www.fao.org/docrep/field/009/as253s/as253s.pdf

Biggs, R., Carpenter, S.R., Brock, W.A., 2009. Turning back from the brink: detecting an impending regime shift in time to avert it. Proc. Natl. Acad. Sci. U. S. A. 106, 826-831. doi:10.1073/pnas.0811729106

Binder, C.R., Hinkel, J., Bots, P.W.G., Pahl-Wostl, C., 2013. Comparison of frameworks for analyzing social-ecological systems. Ecol. Soc. 18, 26. doi:10.5751/ES-05551-180426

Bodin, Ö., Tengö, M., 2012. Disentangling intangible social-ecological systems. Glob. Environ. Chang. 22, 430-439. doi:10.1016/j.gloenvcha.2012.01.005

Bradbear, N., 2009. Bees and their role in forest livelihoods. A guide to the services provided by bees and the sustainable harvesting, processing and marketing of their products. FAO, Rome.

Brockerhoff, E.G., Jactel, H., Parrotta, J.A., Ferraz, S.F.B., 2013. Role of eucalypt and other planted forests in biodiversity conservation and the provision of biodiversity-related ecosystem services. For. Ecol. Manage. 301, 43-50. doi:10.1016/j.foreco.2012.09.018

Brody, S.D., Cash, S.B., Dyke, J., Thornton, S., 2006. Motivations for the forestry industry to participate in collaborative ecosystem management initiatives. For. Policy Econ. 8, 123-134. doi:10.1016/j.forpol.2004.06.002

Brondizio, E.S., Ostrom, E., Young, O.R., 2009. Connectivity and the Governance of Multilevel Social-Ecological Systems: The Role of Social Capital. Annu. Rev. Environ. Resour. 34, 253-278. doi:10.1146/annurev.environ.020708.100707

Brussa, S.C.A., Grela, G.I.A., 2007. Flora arbórea del Uruguay con énfasis en las especies de Rivera y Tacuarembó. COFUSA, Rivera.

Bussoni, A., Juan, C., Fernández, E., Boscana, M., Cubbage, F., Bentancur, O., 2015. Integrated beef and wood production in Uruguay: potential and limitations. Agrofor. Syst. 89, 1107-1118. doi:10.1007/s10457-015-9839-1 
Börner, J., Marinho, E., Wunder, S., 2015. Mixing carrots and sticks to conserve forests in the Brazilian Amazon: a spatial probabilistic modeling approach. PLoS One 10, e0116846. doi:10.1371/journal.pone.0116846

Carpenter, S.R., Cole, J.J., Hodgson, J.R., Kitchell, J.E., Pace, M.L., Bade, D., Cottinngham, K.L., Essington, T.E., Houser, J.N., Schindler, D.E., 2001. Trophic cascades, nutrients, and lake productivity: Whole-lake experiments. Ecol. Monogr. 71, 163186. doi:10.1890/0012-9615(2001)071[0163:tcnalp]2.0.co;2

Cash, D.W., Adger, W.N., Berkes, F., Garden, P., Lebel, L., Olsson, P., Pritchard, L., Young, O., 2006. Scale and Cross-Scale Dynamics: Governance and Information in a Multilevel World. Ecol. Soc. 11, 8. doi:www.ecologyandsociety.org/vol11/iss $2 /$ art8/

CBI, 2015a. Channel and Segments: Honey in Europe. Centre for the Promotion of Imports from developing countries.

CBI, 2015b. Buyer Requirements: Honey in Europe. Centre for the Promotion of Imports from developing countries.

Charnley, S., 2005. Industrial Plantation Forestry. J. Sustain. For. 21, 35-57. doi:10.1300/J091v21n04_04

CHDA, 2011. Sistema Nacional de Trazabilidad de la Miel. CHDA, Montevideo.

Christensen, L., Krogman, N., 2012. Social thresholds and their translation into social-ecological management practices. Ecol. Soc. 17, 9. doi:10.5751/ES-04499-170105

Cinner, J.E., McClanahan, T.R., MacNeil, M.A., Graham, N.A.J., Daw, T.M., Mukminin, A., Feary, D.A., Rabearisoa, A.L., Wamukota, A., Jiddawi, N., Campbell, S.J., Baird, A.H., Januchowski-Hartley, F.A., Hamed, S., Lahari, R., Morove, T., Kuange, J., 2012. Comanagement of coral reef social-ecological systems. Proc. Natl. Acad. Sci. U. S. A. 109, 5219-5222. doi:10.1073/pnas.1121215109

Conforte, D., Plata, V., Inciarte, J.L., 2006. Evolución Histórica de la Apicultura en Uruguay, in: Identificación de Oportunidades de Mejora Y Estrategias Para La Competitividad Internacional Del Cluster de Las Mieles Uruguayas. Universidad ORT, Montevideo, p. 67.

Cossalter, C., Pye-Smith, C., 2003. Fast-wood forestry: myths and realities, Forest Perspectives. Center for International Forestry Research, Bogor. doi:10.17528/cifor/001257

Crane, A., Palazzo, G., Spence, L., Matten, D., 2011. Contesting the Value of “Creating Shared Value.” Calif. Manage. Rev. 56, 130-153. doi:10.1108/09600039410055963

Creswell, J.W., 2003. Research design: qualitative, quantitative, and mixed method approaches, Second. ed. Thousand Oaks, California. doi: $10.2307 / 3152153$

Cubbage, F., Mac Donagh, P., Sawinski, J., Rubilar, R., Donoso, P., Ferreira, A., Hoeflich, V., Olmos, V.M., Ferreira, G., Balmelli, G., Siry, J., Báez, M.N., Alvarez, J., 2007. Timber investment returns for selected plantations and native forests in South America and the southern United States. New For. 33, 237-255. doi:10.1007/s11056-006-9025-4

D’Amato, D., Li, N., Rekola, M., Toppinen, A., Lu, F.-F., 2015. Linking forest ecosystem services to corporate sustainability disclosure: A conceptual analysis. Ecosyst. Serv. 14, 170-178. doi:10.1016/j.ecoser.2014.11.017

DIEA, 2015. Regiones agropecuarias del Uruguay. Dirección de Estadísticas Agropecuarias, Montevideo.

Dirección General Forestal, 2012. Estadísticas y Mercado. Ministerio de Agricultura, Ganadería y Pesca, Montevideo.

Domptail, S., Easdale, M.H., Yuerlita, 2013. Managing Socio-Ecological Systems to Achieve Sustainability: A Study of Resilience and Robustness. Environ. Policy Gov. 23, 30-45. doi:10.1002/eet.1604

Duit, A., Galaz, V., Eckerberg, K., Ebbesson, J., 2010. Governance, complexity, and resilience. Glob. Environ. Chang. 20, $363-368$. doi:10.1016/j.gloenvcha.2010.04.006

Eva, H.D., de Miranda, E.E., Di Bella, C.M., Gond, V., Huber, O., Sgrenzaroli, M., Jones, S., Coutinho, A., Dorado, A., Guimarães, M., Elvidge, C., Achard, F., Belward, A.S., Bartholomé, E., Baraldi, A., De Grandi, G., Vogt, P., Fritz, S., Hartley, A., 2002. A Vegetation Map of South America. Joint Research Centre/European Commission, Ispra.

Faggi, A.M., Zuleta, G. a., Homberg, M., 2014. Motivations for implementing voluntary environmental actions in Argentine forest companies. Land use policy 41, 541-549. doi:10.1016/j.landusepol.2014.04.011

Fahrig, L., 2003. Effects of habitat fragmentation on biodiversity. Annu. Rev. Ecol. Evol. Syst. 34, 487-515. doi:10.1146/annurev.ecolsys.34.011802.132419

Farley, K., Jobbágy, E.G., Jackson, R.B., 2005. Effects of afforestation on water yield: A global synthesis with implications for policy. Glob. Chang. Biol. 11, 1565-1576. doi:10.1111/j.1365-2486.2005.01011.x 
Folke, C., 2006. Resilience: The emergence of a perspective for social-ecological systems analyses. Glob. Environ. Chang. 16, 253267. doi:10.1016/j.gloenvcha.2006.04.002

Folke, C., Carpenter, S., Elmqvist, T., Gunderson, L., Holling, C.S., Walker, B., 2002. Resilience and Sustainable Development: Building Adaptive Capacity in a World of Transformations. Ambio 31, 437-440. doi:10.1579/0044-7447-31.5.437

Folke, C., Carpenter, S., Walker, B., Scheffer, M., Elmqvist, T., Gunderson, L., Holling, C.S., 2004. Regime shifts, resilience, and biodiversity in ecosystem management. Annu. Rev. Ecol. Evol. Syst. 35, 557-581. doi:10.1146/annurev.ecolsys.35.021103.105711

Gallai, N., Salles, J.M., Settele, J., Vaissière, B.E., 2009. Economic valuation of the vulnerability of world agriculture confronted with pollinator decline. Ecol. Econ. 68, 810-821. doi:10.1016/j.ecolecon.2008.06.014

Gerber, J.F., 2011. Conflicts over industrial tree plantations in the South: Who, how and why? Glob. Environ. Chang. 21, $165-176$. doi:10.1016/j.gloenvcha.2010.09.005

Gray, C.L., Bilsborrow, R.E., 2014. Consequences of out-migration for land use in rural Ecuador. Land use policy 36, $182-191$. doi:10.1016/j.landusepol.2013.07.006

Hanley, N., Breeze, T.D., Ellis, C., Goulson, D., 2014. Measuring the economic value of pollination services: Principles, evidence and knowledge gaps. Ecosyst. Serv. 14, 1-9. doi:10.1016/j.ecoser.2014.09.013

Hedlund, M., Lundholm, E., 2015. Restructuring of rural Sweden - Employment transition and out-migration of three cohorts born 1945-1980. J. Rural Stud. 42, 123-132. doi:10.1016/j.jrurstud.2015.10.006

Holling, C.S., 2001. Understanding the Complexity of Economic, Ecological, and Social Systems. Ecosystems 4, 390-405. doi:10.1007/s10021-00

Hunt, L.M., Sutton, S.G., Arlinghaus, R., 2013. Illustrating the critical role of human dimensions research for understanding and managing recreational fisheries within a social-ecological system framework. Fish. Manag. Ecol. 20, 111-124. doi:10.1111/j.1365-2400.2012.00870.x

Hunt, T.L., Lipo, C.P., 2009. Revisiting Rapa Nui (Easter Island) “Ecocide.” Pacific Sci. 63, 601-616. doi:10.2984/049.063.0407

Ingram, V., Schure, J., Tieguhong, J.C., Ndoye, O., Awono, A., Iponga, D.M., 2014. Gender implications of forest product value chains in the Congo basin. For. Trees Livelihoods 23, 67-86. doi:10.1080/14728028.2014.887610

Ingram, V., Van Der Werf, E., Kikulwe, E., Wesseler, J.H.H., 2016. Evaluating the impacts of plantations and associated forestry operations in Africa: methods and indicators. Int. For. Rev. 18, 44-55. doi:10.1505/146554816818206087

Janssen, M.A., Ostrom, E., 2006. Governing Social-Ecological Systems, in: Tesfatsion, L., Judd, K.L. (Eds.), Handbook of Computational Economics: Agent-Based Computational Economics. North-Holland, Amsterdam, pp. 1465-1509. doi:10.1016/S1574-0021(05)02030-7

Janssen, M.A., Scheffer, M., 2004. Overexploitation of renewable resources by ancient societies and the role of sunk-cost effects. Ecol. Soc. 9, 1-6. doi:www.ecologyandsociety.org/vol9/iss1/art6/

Klein, A.-M., Vaissière, B.E., Cane, J.H., Steffan-Dewenter, I., Cunningham, S. a, Kremen, C., Tscharntke, T., 2007. Importance of pollinators in changing landscapes for world crops. Proc. R. Soc. B 274, 303-313. doi:10.1098/rspb.2006.3721

Korhonen, J., Toppinen, A., Cubbage, F., Kuuluvainen, J., 2014. Factors driving investment in planted forests: a comparison between OECD and non-OECD countries. Int. For. Rev. 16, 67-77. doi:10.1505/146554814811031314

Kovács, E., Kelemen, E., Kalóczkai, Á., Margóczi, K., Pataki, G., Gébert, J., Málovics, G., Balázs, B., Roboz, Á., Krasznai Kovács, E., Mihók, B., 2014. Understanding the links between ecosystem service trade-offs and conflicts in protected areas. Ecosyst. Serv. 12, 117-127. doi:10.1016/j.ecoser.2014.09.012

Ledford, H., 2015. Brazil considers transgenic trees. Nat. News 512, 357. doi:10.1038/512357a

Lescourret, F., Magda, D., Richard, G., Adam-Blondon, A.F., Bardy, M., Baudry, J., Doussan, I., Dumont, B., Lefevre, F., Litrico, I., Martin-Clouaire, R., Montuelle, B., Pellerin, S., Plantegenest, M., Tancoigne, E., Thomas, A., Guyomard, H., Soussana, J.F., 2015. A social-ecological approach to managing multiple agro-ecosystem services. Curr. Opin. Environ. Sustain. 14, 68-75. doi:10.1016/j.cosust.2015.04.001

Liu, J., Mooney, H., Hull, V., Davis, S.J., Gaskell, J., Hertel, T., Lubchenco, J., Seto, K.C., Gleick, P., Kremen, C., Li, S., 2015. Systems integration for global sustainability. Science (80-. ). 347, 1258832-1258832. doi:10.1126/science.1258832

McGinnis, M.D., Ostrom, E., 2014. Social-ecological system framework: initial changes and continuing challenges. Ecol. Soc. 19, 
30. doi:10.5751/ES-06387-190230

MGAP, 2015. Anuario Estadístico Agropecuario. Ministerio de Agricultura, Ganadería y Pesca, Montevideo.

Michelini, L., Fiorentino, D., 2012. New business models for creating shared value. Soc. Responsib. J. 8, 561-577. doi:10.1108/17471111211272129

Miles, M.B., Huberman, M.A., 1994. Qualitative data analysis: An expanded sourcebook, Second. ed, Qualitative data analysis: An expanded sourcebook. SAGE, California.

Montes del Plata, 2015. Plan de Gestión Forestal y Resultados de Monitoreo: Resumén Público (Edición: marzo 2015). Montevideo.

Moser, S.C., Ekstrom, J.A., 2010. A framework to diagnose barriers to climate change adaptation. Proc. Natl. Acad. Sci. U. S. A. 107, 22026-22031. doi:10.1073/pnas.1007887107

Mwangi, E., Ostrom, E., 2009. A Century of Institutions and Ecology in East Africa's Rangelands: Linking Institutional Robustness with the Ecological Resilience of Kenya's Maasailand, in: Beckmann, V., Padmanabhan, M. (Eds.), Institutions and Sustainability: Political Economy of Agriculture and the Environment - Essays in Honour of Konrad Hagedorn. Springer Netherlands, Amsterdam, pp. 195-222. doi:10.1007/978-1-4020-9690-7_10

Naeem, S., Ingram, J.C., Varga, A., Agardy, T., Barten, P., Bennett, G., Bloomgarden, E., Bremer, L.L., Burkill, P., Cattau, M., Ching, C., Colby, M., Cook, D.C., Costanza, R., Declerck, F., Freund, C., Gartner, T., Gunderson, J., Jarrett, D., Kinzig, A.P., Kiss, A., Koontz, A., Kumar, P., Lasky, J.R., Masozera, M., Meyers, D., Milano, F., Nichols, E., Olander, L., Olmsted, P., Perge, E., Perrings, C., Polasky, S., Potent, J., Prager, C., Quétier, F., Redford, K., Saterson, K., Thoumi, G., Vargas, M.T., Vickerman, S., Weisser, W., Wilkie, D., Wunder, S., 2015. Get the science right when paying for nature's services. Science 347, 1206-1207. doi:10.1126/science.aaa1403

Nelson, E., Mendoza, G., Regetz, J., Polasky, S., Tallis, H., Cameron, D.R., Chan, K.M.A., Daily, G.C., Goldstein, J., Kareiva, P.M., Lonsdorf, E., Naidoo, R., Ricketts, T.H., Shaw, M.R., 2009. Modeling multiple ecosystem services, biodiversity conservation, commodity production, and tradeoffs at landscape scales. Front. Ecol. Environ. 7, 4-11. doi:10.1890/080023

Nkhata, B.A., Mosimane, A., Downsborough, L., Breen, C., Roux, D.J., 2012. A Typology of Benefit Sharing Arrangements for the Governance of Social-Ecological Systems in Developing Countries. Ecol. Soc. 17, 17. doi:10.5751/ES-04662-170117

Paruelo, J.M., 2012. Ecosystem services and tree plantations in Uruguay: A reply to Vihervaara et al. (2012). For. Policy Econ. 22, 85-88. doi:10.1016/j.forpol.2012.04.005

Porter, M., Kramer, M., 2011. Creating Shared Value. Harv. Bus. Rev. 89, 63-70. doi:10.1108/09600039410055963

Porter, M.E., Kramer, M.R., 2006. Strategy \& Society: The Link Between Competitive Advantage and Corporate Social Responsibility. Harv. Bus. Rev. 84, 78-92. doi:10.1287/mnsc.1090.1070

Potts, S.G., Biesmeijer, J.C., Kremen, C., Neumann, P., Schweiger, O., Kunin, W.E., 2010. Global pollinator declines: Trends, impacts and drivers. Trends Ecol. Evol. 25, 345-353. doi:10.1016/j.tree.2010.01.007

Preisler, D., 2015. Brazil approves GM eucalyptus. Nat. News 520, 268-269. doi:10.1038/520268a

Prejer, B., Levall, S., Mark-Herbert, C., 2014. Developing business models for alleviating poverty: a case study of Stora Enso in Lao PDR, in: Gudic, M., Rosenbloom, A., Parkes, C. (Eds.), Socially Responsible Organizations and the Challenge of Poverty. Greenleaf, Sheffield, pp. 91-102.

Rainbird, P., 2002. A message for our future? The Rapa Nui (Easter Island) ecodisaster and Pacific island environments. World Archaeol. 33, 436-451. doi:10.1080/00438240120107468

Rathwell, K.J., Peterson, G.D., 2012. Connecting Social Networks with Ecosystem Services for Watershed Governance: a SocialEcological Network Perspective Highlights the Critical Role of Bridging Organizations. Ecol. Soc. 17, 24. doi:10.5751/ES04810-170224

Reddy, P.V.R., Verghese, A., Rajan, V.V., 2013. Potential impact of climate change on honeybees (Apis spp.) and their pollination services. Pest Manag. Hortic. Ecosyst. 18, 121-127.

Renaud, F.G., Birkmann, J., Damm, M., Gallopín, G.C., 2010. Understanding multiple thresholds of coupled social-ecological systems exposed to natural hazards as external shocks. Nat. Hazards 55, 749-763. doi:10.1007/s11069-010-9505-x

Rudel, T.K., Schneider, L., Uriarte, M., 2010. Forest transitions: An introduction. Land use policy 27, 95-97. doi:10.1016/j.landusepol.2009.09.021

Rönnberg, C., Bonsdorff, E., 2004. Baltic Sea eutrophication: Area-specific ecological consequences. Hydrobiologia 514, $227-241$. 
doi:10.1023/B:HYDR.0000019238.84989.7f

Scheffer, M., Carpenter, S., Foley, J., Folke, C., Walker, B., 2001. Catastrophic shifts in ecosystems. Nature 413, 591-596. doi: $10.1038 / 35098000$

Shuy, R.W., 2002. In-person versus telephone interviewing, in: Gubrium, J., Holstein, J. (Eds.), Handbook of Interview Research: Context \& Method. SAGE, California, pp. 537-555.

Silveira, L., Alonso, J., 2009. Runoff modifications due to the conversion of natural grasslands to forests in a large basin in Uruguay. Hydrol. Process. 23, 320-329. doi:10.1002/hyp.7156

Strano, A., Stillitano, T., De Luca, A.I., Falcone, G., Gulisano, G., 2015. Profitability analysis of small-scale beekeeping firms by using life cycle costing (LCC) methodology. Am. J. Agric. Biol. Sci. 10, 116-127. doi:10.3844/ajabssp.2015.116.127

Strauss, A., Corbin, J., 1990. Grounded Theory Research: Procedures, Canons, and Evaluative Criteria. Qual. Sociol. 13, 3-21. doi:10.1007/BF00988593

Sunderlin, W.D., Dewi, S., Puntodewo, A., M??ller, D., Angelsen, A., Epprecht, M., 2008. Why forests are important for global poverty alleviation: A spatial explanation. Ecol. Soc. 13, 24. doi:www.ecologyandsociety.org/vol13/iss2/art24/

Switzer, M.B., 2014. Planting Progress? The Everyday Impacts of Plantation Forestry on Small Farmers in Interior Uruguay. Environ. Justice 7, 77-80. doi:10.1089/env.2013.0032

Thomas, D., Henson, M., Joe, B., Boyton, S., Dickson, R., 2009. Review of growth and wood quality of plantation-grown Eucalyptus dunnii Maiden. Aust. For. 72, 3-11. doi:10.1080/00049158.2009.10676283

Thompson, H.M., Levine, S.L., Doering, J., Norman, S., Manson, P., Sutton, P., von Mérey, G., 2014. Evaluating exposure and potential effects on honeybee brood (Apis mellifera) development using glyphosate as an example. Integr. Environ. Assess. Manag. 10, 463-470. doi:10.1002/ieam.1529

Tommasino, H., 2010. 15 años de cambios en el agro uruguayo: impacto en la ganadería vacuna, in: Anuario de OPYPA. Montevideo, pp. 365-381.

Toppinen, A., Zhang, Y., Laaksonen-Craig, S., Lähtinen, K., Weng, G., Mery, G., Katila, P., Galloway, G., Alfaro, R.I., Kanninen, M., Lobovikov, M., Varjo, J., 2010. Changes in Global Markets for Forest Products and Timberlands, in: Mery, G., Katila, P., Galloway, G., Alfaro, R.I., Kanninen, M., Lobovikov, M., Varjo, J. (Eds.), Forests and Society - Responding to Global Drivers of Change. IUFRO, Vienna, pp. 137-156.

Tucker, C.M., 2010. Learning on Governance in Forest Ecosystems: Lessons from Recent Research. Int. J. Commons 4, 687-706. doi:10.18352/ijc.224

UPM Forestal Oriental, 2013. Innovador acuerdo entre UPM Forestal Oriental e instituciones apícolas. Montevideo.

Urcola, H.A., de Sartre, X.A., Veiga, I., Elverdin, J., Albaladejo, C., 2015. Land tenancy, soybean, actors and transformations in the pampas: A district balance. J. Rural Stud. 39, 32-40. doi:10.1016/j.jrurstud.2015.03.001

Uruguay XXI, 2014. Sector apícola. Montevideo.

Walker, B.H., Carpenter, S.R., Rockstrom, J., Cr??pin, A.S., Peterson, G.D., 2012. Drivers, "Slow” Variables, "Fast” Variables, Shocks, and Resilience. Ecol. Soc. 17, 30. doi:10.5751/ES-05063-170330

Walker, B.H., Gunderson, L., Kinzig, A., Folke, C., Carpenter, S., Schultz, L., 2006. A Handful of Heuristics and Some Propositions for Understanding Resilience in Social-Ecological Systems. Ecol. Soc. 11, 13. doi:www.ecologyandsociety.org/vol11/iss1/art13/

Walker, B.H., Holling, C.S., Carpenter, S.R., Kinzig, A., 2004. Resilience, Adaptability and Transformability in Social-ecological Systems. Ecol. Soc. 9, 5. doi:www.ecologyandsociety.org/vol9/iss2/art5/

Walker, B.H., Meyers, J.A., 2004. Thresholds in ecological and social-ecological systems: A developing database. Ecol. Soc. $9,3$. doi:www.ecologyandsociety.org/vol9/iss2/art3/

Walker, B.H., Pearson, L., 2007. A resilience perspective of the SEEA. Ecol. Econ. 61, 708-715. doi:10.1016/j.ecolecon.2006.04.010

Wang, S., Fu, B., 2013. Trade-offs between forest ecosystem services. For. Policy Econ. 26, 145-146. doi:10.1016/j.forpol.2012.07.014

Warren, C.A.B., 2002. Qualitative Interviewing, in: Gubrium, J.F., Holstein, J.A. (Eds.), Handbook of Interview Research: Context \& Method. SAGE, California, pp. 83-101. 
Vieira, L.M., Maia, T., 2009. The governance of fair trade system: Evidence from small honey producers in Rio Grande do Sul. Brazilian Adm. Rev. 6, 367-379. doi:10.1590/S1807-76922009000400007

Vihervaara, P., Kamppinen, M., Kumpula, T., Walls, M., 2013. Biodiversity trade-offs and globalizing forestry. For. Policy Econ. 26, 147-148. doi:10.1016/j.forpol.2012.10.003

Vihervaara, P., Marjokorpi, A., Kumpula, T., Walls, M., Kamppinen, M., 2012. Ecosystem services of fast-growing tree plantations: A case study on integrating social valuations with land-use changes in Uruguay. For. Policy Econ. 14, 58-68. doi:10.1016/j.forpol.2011.08.008

Villanueva-Gutiérrez, R., Echazarreta-González, C., Roubik, D.W., Moguel-Ordóñez, Y.B., 2014. Transgenic soybean pollen (Glycine max L.) in honey from the Yucatán peninsula, Mexico. Sci. Rep. 4, 4022. doi:10.1038/srep04022

Vincent, K., 2007. Uncertainty in adaptive capacity and the importance of scale. Glob. Environ. Chang. 17, 12-24. doi:10.1016/j.gloenvcha.2006.11.009

Volante, J., Mosciaro, J., Morales Poclava, M., Vale, L., Castrillo, S., Sawchik, J., Tiscornia, G., Fuente, M., Maldonado, I., Vega, A., Trujillo, R., Cortéz, L., Paruelo, J., 2015. Agricultural expansion in Argentina, Bolivia, Paraguay, Uruguay and Chile between 2000-2010. Spatial characterization using time series vegetation indices. Rev. Investig. Agropecu. 41, $179-191$.

Zenteno, M., de Jong, W., Boot, R., Zuidema, P.A., 2014. Learning from the past: Trends and dynamics in livelihoods of Bolivian forest communities. Environ. Sci. Policy 40, 36-48. doi:10.1016/j.envsci.2014.03.006 